ARTICLE

https://doi.org/10.1038/s41467-018-07934-z

\title{
Age and pattern of the southern high-latitude continental end-Permian extinction constrained by multiproxy analysis
}

Christopher R. Fielding (1) 1, Tracy D. Frank (1) ', Stephen McLoughlin (10 2, Vivi Vajda (i) 2, Chris Mays², Allen P. Tevyaw ${ }^{1}$, Arne Winguth ${ }^{3}$, Cornelia Winguth ${ }^{3}$, Robert S. Nicoll ${ }^{4}$, Malcolm Bocking ${ }^{5}$ \& James L. Crowley ${ }^{6}$

Past studies of the end-Permian extinction (EPE), the largest biotic crisis of the Phanerozoic, have not resolved the timing of events in southern high-latitudes. Here we use palynology coupled with high-precision CA-ID-TIMS dating of euhedral zircons from continental sequences of the Sydney Basin, Australia, to show that the collapse of the austral Permian Glossopteris flora occurred prior to 252.3 Ma ( 370 kyrs before the main marine extinction). Weathering proxies indicate that floristic changes occurred during a brief climate perturbation in a regional alluvial landscape that otherwise experienced insubstantial change in fluvial style, insignificant reorganization of the depositional surface, and no abrupt aridification. Palaeoclimate modelling suggests a moderate shift to warmer summer temperatures and amplified seasonality in temperature across the EPE, and warmer and wetter conditions for all seasons into the Early Triassic. The terrestrial EPE and a succeeding peak in Ni concentration in the Sydney Basin correlate, respectively, to the onset of the primary extrusive and intrusive phases of the Siberian Traps Large Igneous Province.

\footnotetext{
${ }^{1}$ Department of Earth \& Atmospheric Sciences, University of Nebraska-Lincoln, 126 Bessey Hall, Lincoln, NE 68588-0340, USA. ${ }^{2}$ Swedish Museum of Natural History, Box 50007 S-104 05 Stockholm, Sweden. ${ }^{3}$ Department of Earth \& Environmental Sciences, University of Texas at Arlington, PO Box 19049 Arlington, TX 76019, USA. ${ }^{4}$ Geoscience Australia, GPO Box 378 Canberra, ACT 2601, Australia. ${ }^{5}$ Bocking Associates, 8 Tahlee Close, Castle Hill, NSW 2154, Australia. ${ }^{6}$ Isotope Geology Laboratory, Boise State University, 1910 University Drive, Boise, ID 83725-1535, USA. Correspondence and requests for materials should be addressed to C.R.F. (email: cfielding2@unl.edu)
} 
S tudies of past climate transitions facilitate evaluation of future conditions in a time of rapid environmental change. The Late Permian to Early Triassic was marked by major perturbations to the Earth system, including the largest mass extinction of the geological record ${ }^{1,2}$. This interval saw the final assembly of Pangea, a minimum in the extent of continental flooding by the sea, the development of megamonsoonal climates, and unprecedented expansion of subtropical arid belts ${ }^{1}$. Geochemical proxy records reveal an Earth system susceptible to perturbation by abrupt events that may have included outgassing from the Siberian Trap Large Igneous Province (LIP) ${ }^{3-5}$ and fly ash emission from intrusions into the West Siberian Coal Basin $^{6,7}$. Ocean acidification ${ }^{8}$, anoxia and euxinia ${ }^{9}$, and ozone depletion ${ }^{10}$ culminated in the end-Permian extinction (EPE). Such processes find parallels in the past two centuries affected by widespread deforestation, land-use changes, decline in biodiversity, and anthropogenic-induced climate change and ocean acidification, hence the signature of physical change and biotic turnover at the EPE may provide lessons for the management of modern terrestrial ecosystems.

Most research into the EPE has targeted marine records because these are perceived as the most stratigraphically complete and likely to preserve globally integrated signals ${ }^{11}$. However, the continental record, particularly the sedimentological and palaeovegetation signal, is receiving increasing attention because this system is predicted to be most strongly affected by future climate change and is most relevant to human society. Major biotic changes in both the marine and non-marine systems began well before the end-Permian, at the Guadalupian-Lopingian (middle-late Permian) boundary ${ }^{12,13}$, although the severity of this early event is debated ${ }^{14}$. The main extinction phase is considered to have occurred shortly before the Permian-Triassic boundary and to have been short-lived $(60 \mathrm{kyrs})^{2}$. However, some marine records indicate delayed extinction in deep palaeowater depths ${ }^{15}$ and other work suggests that a second extinction episode in the earliest Triassic followed the main kill event ${ }^{16,17}$.

The continental record of the EPE has been interpreted to signal a massive spike in soil erosion associated with devegetation, climate warming, and periods of acidic rainfall ${ }^{18}$. Concurrent aridification has been inferred in some cases (e.g. Karoo Basin $\left.{ }^{19,20}\right)$, despite data from mudrocks and palaeosols from that basin suggesting that earliest Triassic environments were in fact wetter than their latest Permian counterparts ${ }^{21}$. A long-term, global aridification trend has been inferred ${ }^{18}$.

Several researchers have attributed an inferred change in fluvial style across the boundary from the $\mathrm{Karoo}^{22,23}$ and other basins ${ }^{24,25}$ to catastrophic environmental change, whereas other areas show no such change $\mathrm{e}^{26}$. As in the marine realm, it seems that terrestrial responses to the biotic crisis were varied and complex. For example, $\delta^{13} \mathrm{C}_{\text {org }}$, sedimentological, and palynological results from four terrestrial to marine Permian-Triassic successions of South China show that the system boundary is marked by a rapid carbon isotope shift $^{27}$, a gradual transition from fluvio-lacustrine to lagoonal-littoral deposits, strong vegetation turnover ${ }^{28}$, and the occurrence of fungal spores together with the putative algal/fungal 'disaster taxon' Reduviasporonites ${ }^{29}$, collectively interpreted to reflect a collapse of complex ecosystems and proliferation of decomposers during the EPE. Thus multidisciplinary approaches are key to interpreting environments through the Permian-Triassic transition.

Geochronological constraints on Permian-Triassic events in most continental basins studied to date are poor. In contrast, the Sydney-Gunnedah-Bowen Basin system in eastern Australia preserves a stratigraphically complete, less thoroughly documented, but well-calibrated Lopingian to Lower Triassic record that is investigated herein. The Sydney Basin of central New

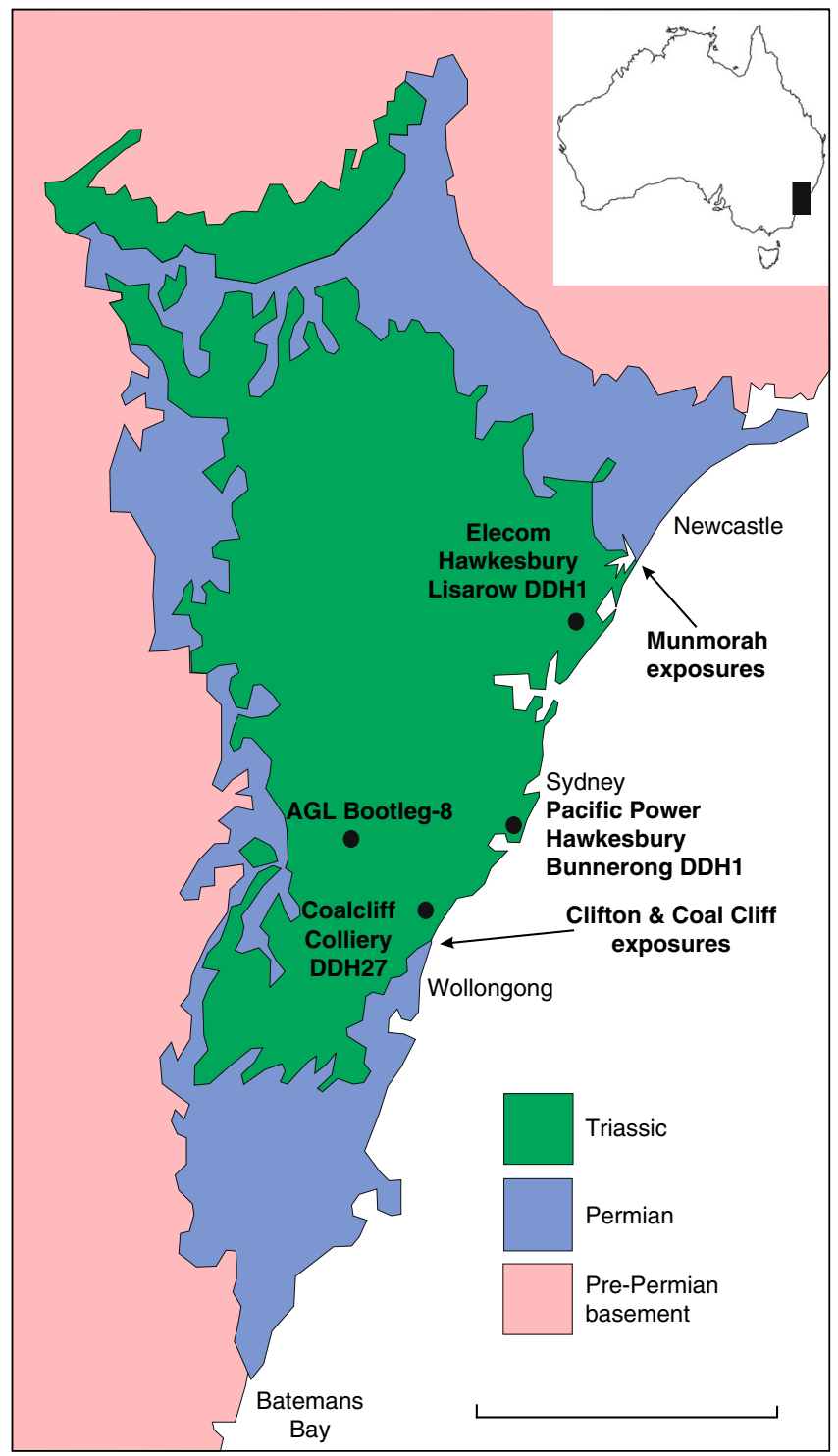

Fig. 1 Maps of field and drillhole locations. Location of the Sydney Basin in southeast Australia and generalized geology of the Sydney Basin. Locations of field exposures and drillcores examined in this paper are also shown. Scale bar $100 \mathrm{~km}$. Geology simplified and redrawn after New South Wales Geological Survey 1:500,000 Special Sheet Map of Sydney Basin (1969)

South Wales (Fig. 1) preserves a thick Permo-Triassic sedimentary succession exposed in coastal cliffs north and south of Sydney ${ }^{30}$ and penetrated by hundreds of boreholes. Historically, the Permo-Triassic boundary (PTB) has been placed at the top of the uppermost coal seam in the succession (Bulli Coal in the south, Katoomba Coal Member in the west, and Vales Point coal seam in the north of the basin $\left.{ }^{31}\right)$. Recent high-precision chemical abrasion isotope dilution thermal ionization mass spectrometry (CA-ID-TIMS) dating of tuffs and recalibration of palynological zones in eastern Australian basins have resulted in divergent opinions about placement of the PTB with respect to local biozonations and lithostratigraphy. The PTB was equated ${ }^{32,33}$ with the first common occurrence of Lunatisporites pellucidus within the Wombarra Shale or Scarborough Sandstone of the Narrabeen Group (around $40-80 \mathrm{~m}$ above the uppermost coal) or alternatively ${ }^{34}$ at the top of the Illawarra Coal Measures. Regardless of the placement of the system boundary, there is a consensus that 
the major crisis in terrestrial ecosystems occurred around the end of coal accumulation in the eastern Australian basins $24,33,34$.

Here we use additional radiometric, palaeobotanical, and sedimentological data to identify the stratigraphic position of the end-Permian biotic crisis in a continental southern high-latitude setting and constrain its age to $\sim 410$ kyrs before age of the the PTB defined at Meishan, China. Moreover, we use the sedimentological and geochemical signals from a fully cored Permian-Triassic transitional interval in tandem with palaeoclimatic modelling to infer that the biotic crisis was accompanied by a short-term intensification of weathering within a longer-term regime of warming and amplified seasonality that played out on an alluvial landscape that experienced minimal changes in regional depositional style.

\section{Results and Discussion}

The Permian-Triassic boundary in the Sydney Basin. We document a reference section for the long-term patterns of sedimentological, isotopic, floristic, and environmental change through the Lopingian and Lower Triassic succession based on the fully cored borehole Pacific Power Hawkesbury Bunnerong DDH1 (henceforth, PHKB1), drilled in the synclinal axis of the Sydney Basin near the Port of Botany, Sydney (Fig. 1). Age calibration of this southern high-latitude succession is provided by CA-ID-TIMS dating of tuffs from the present and previous studies $^{33,35}$ or, where ash beds are unavailable, by palynostratigraphic correlation to dated successions elsewhere across Gondwana (Fig. 2). The metadata for all ages are given in Supplementary document.

The boundary between the Dulhuntyispora parvithola and Playfordiaspora crenulata palynozones identified herein at the top of the Bulli Coal (and equivalents) in the Sydney Basin marks the most pronounced floristic turnover (characterized by the collapse of glossopterid mire communities) in the succession (Fig. 2) and is equated with the continental EPE herein. High-precision U-Pb CA-TIMS dating of a tuff from the lower part of the Bulli Coal in Metropolitan Colliery at Helensburgh, north of Coalcliff, has yielded an age of $252.60 \pm 0.04 \mathrm{Ma}$ (mid-Changhsingian ${ }^{33}$ ). A new date of $252.31 \pm 0.07 \mathrm{Ma}$ (late Changhsingian) was obtained from a dark grey, organic-rich shale bed immediately overlying the Bulli Coal at Coalcliff (Fig. 2, Supplementary Fig. 1; Supplementary Tables 1 and 2). No evidence of physical working of sediment (grain-size differentiated lamination, physical sedimentary structures) was evident from this bed, and the zircon grains analysed were all euhedral and unabraded (Supplementary Fig. 2). Furthermore, volcanic fallout debris is abundant within this interval. On this basis, we argue that the age is based on primary, volcanic zircon grains and not grains reworked from older sediments.

The $252.31 \pm 0.07 \mathrm{Ma}$ age provides a constraint for the collapse of the Glossopteris flora, dated some 410,000 years older than the age obtained for the Global Stratotype Section and Point (GSSP) for the PTB at Meishan, China ${ }^{2}$. Furthermore, we have preliminary, as yet unconfirmed, ages in the range $251-252 \mathrm{Ma}$ from samples within the Coal Cliff Sandstone (Fig. 2), which suggest that this unit may be of earliest Triassic age. Other authors have favoured placement of the PTB at the base, or within the lower part, of the $L$. pellucidus Palynozone ${ }^{33,34,36,37}$, in which case the PTB would be placed around $45 \mathrm{~m}$ above the Bulli Coal in PHKB1, within the upper Wombarra Shale (Fig. 2).

Sedimentology. PHKB1 terminated in diversely bioturbated, invertebrate fossil- and glendonite-bearing sandstones (Erins Vale Formation, Cumberland Subgroup, Illawarra Coal Measures) of latest middle Permian age at $1251.05 \mathrm{~m}$. These are interpreted as (glacio)marine strata of a shallow marine shelf. The uppermost indications of cold sea-floor conditions in this core are at 1212.60 $\mathrm{m}$, representing the termination of the ultimate (P4) glacial interval of the Late Palaeozoic Ice Age in eastern Australia ${ }^{38}$. The top of the shelfal unit at $1172.56 \mathrm{~m}$ marks the Guadalupian-Lopingian boundary and corresponds to a major unconformity surface that can be traced across the basin ${ }^{39}$. The overlying Lopingian part of the Illawarra Coal Measures (Sydney Subgroup) is heterolithic and includes several coarsening-upward cycles interpreted as the record of deltaic progradational episodes. Marine invertebrate fossils are very rare in this succession, but trace fossil assemblages of reduced ichnodiversity (compared to the underlying Erins Vale Formation) indicate an array of highly stressed paralic environments ${ }^{40}$. Erosionally based, cross-bedded sandstone bodies of coastal plain fluvial channel origin become successively more abundant upward from about the middle of the Illawarra Coal Measures, interbedded with coal seams interpreted as the record of coastal plain mires (Fig. 2). These strata are typified by rich assemblages of Glossopteris leaves in finely laminated facies and by Vertebraria (glossopterid) roots in immature palaeosols. Channel facies in the Lopingian succession show evidence of strong seasonality in discharge, with upright in situ tree stumps in some channel-floor deposits. A restricted suite of simple, facies-crossing trace fossils characterizes these channel bodies and the interbedded heterolithic facies, and there are indicators of tidal modulation of fluvial outflow (paired mud drapes, rhythmic pinstripe lamination) at several stratigraphic levels.

The core is somewhat disturbed immediately below the level of the putative EPE; the uppermost coal (Bulli Coal) is intruded by thin dolerite sills and much of it was removed for analysis at the time of drilling. In PHKB1, and in various other sections around the Sydney Basin, the uppermost coal is succeeded by a package of $1-5 \mathrm{~m}$ of dark grey mudstones grading into lighter grey siltstones, which are in turn overlain by coarse-grained sandstones or conglomerates (Fig. 3). The mudstone-siltstone package includes high abundances of amorphous organic matter (AOM) and sporadic phytoplankton typical of aquatic conditions. In some parts of the basin, the sandstone/conglomerate packages lie directly on the uppermost coal with a locally scoured, but not unconformable, contact. The strata overlying the Bulli Coal indicate a continuation of similar sedimentary facies associations and depositional environments (albeit lacking coal). These overlying lithostratigraphic units (successively, the Coal Cliff Sandstone, Wombarra Shale, Scarborough Sandstone, Stanwell Park Claystone, and Bulgo Sandstone) are variably dominated by sandstones or mudrocks. Sandstone bodies are essentially unchanged in grain size, composition, internal sedimentary structures, thickness, and palaeocurrent orientations, suggesting no major change in fluvial style (mobile, sand, and gravel bed rivers) across the EPE or PTB with the exception of the termination of peat accumulation. Mudrocks remain grey or olive-grey for around $400 \mathrm{~m}$ into the Lower Triassic succession. Trace fossils and other coastal indicators die out upward, suggesting that the depositional environment became successively more inland fluvial in aspect over time. Approximately $400 \mathrm{~m}$ above the EPE horizon in PHKB1, mudrocks become conspicuously reddened (Fig. 2).

Palaeofloras. Coal seams of the Illawarra and Newcastle Coal Measures throughout the Sydney Basin are consistently underlain by Vertebraria (glossopterid) roots and numerous clastic layers within and above the coals host matted Glossopteris leaves, indicating the extensive contribution of glossopterid gymnosperms to the (par)autochthonous accumulation of peat in the 


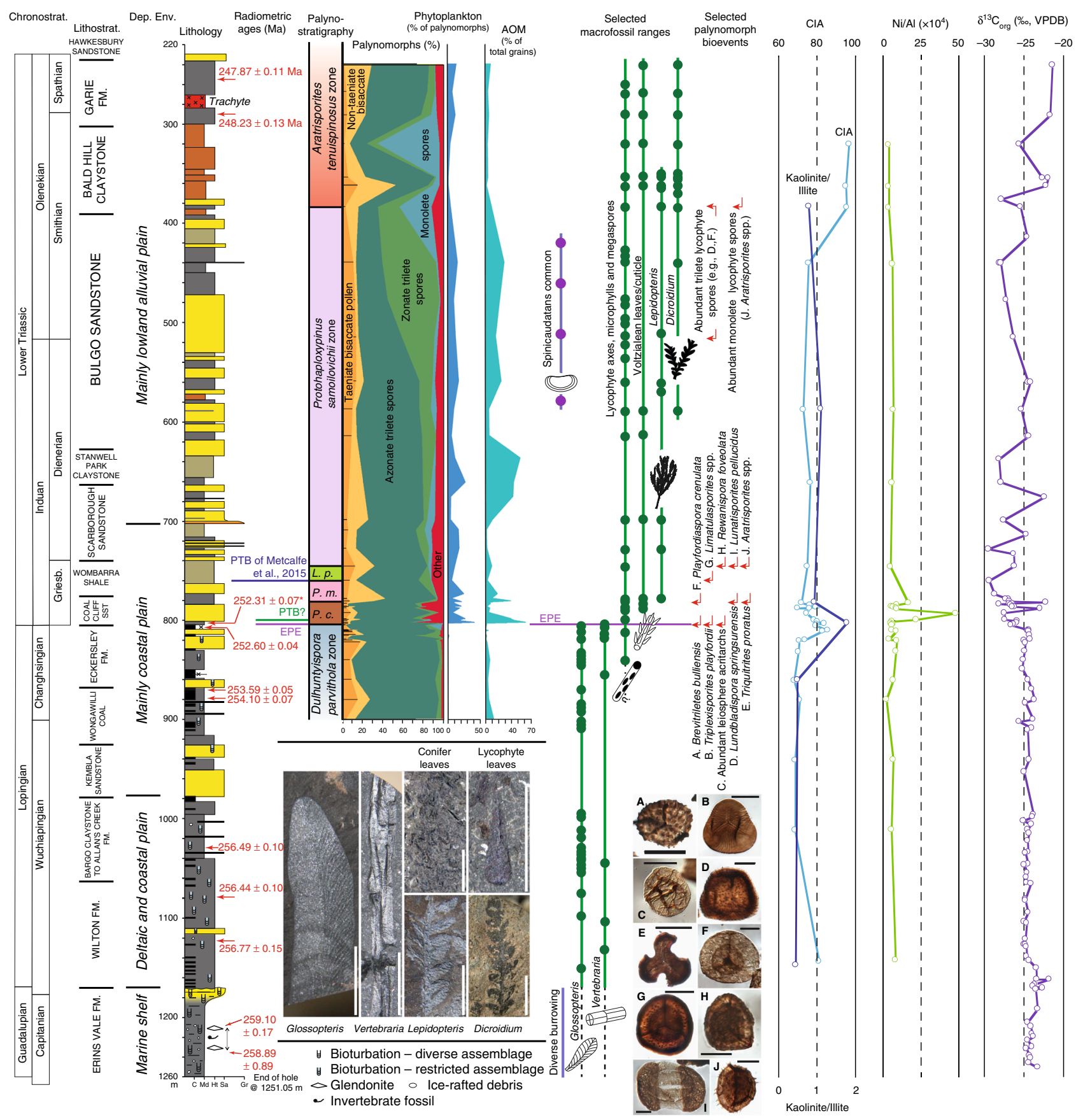

Fig. 2 Graphical log of Pacific Power Hawkesbury Bunnerong DDH-1 (PHKB1) well core. PHKB1 is located in the synclinal axis of the Sydney Basin (Fig. 1). Stratigraphy is tied to the chronostratigraphic scale of ref. ${ }^{78}$ (updated 2017) using new CA-ID-TIMS U-Pb ages (indicated by an asterisk) and those of refs. ${ }^{33,35}$. Correlation of lithostratigraphic units to all stage and substage boundaries remains tentative. Log shows lithologies (C coal, Md mudrocks, $\mathrm{Ht}$ heterolithic, interlaminated siltstone and sandstone, Sa sandstone, Gr conglomerate), with approximate representation of colour for mudrocks, and generalized interpretation of depositional environment. Selected plant group ranges based on macrofossils and dispersed cuticle recovered from core samples indicate the major turnover in the floras inferred to represent the EPE. First appearance datums of selected palynomorph taxa provide the basis for recognizing the local palynozones $36,37,76$. Two alternative positions are indicated for the PTB-a lower position, near the base of the $P$. crenulatus Palynozone, inferred on the basis of preliminary new CA-IDTIMS ages; and a higher position, near the base of the L. pellucidus Palynozone, based on ref. 33 . Scale bars for plant macrofossils $=10 \mathrm{~mm}$; for palynomorphs $=20 \mu \mathrm{m}$. Also shown are kaolinite/illite ratios, Chemical Index of Alteration (CIA), Nickel concentration normalized to $\mathrm{Al}$, and $\delta^{13} \mathrm{C}_{\text {org }}$ values through the upper Permian and Lower Triassic succession of PHKB-1. Dep. Env. = inferred depositional environment, P. c. = Playfordiaspora crenulata Palynozone, P. $m$. = Protohaploxypinus microcorpus Palynozone, L. p. = Lunatisporites pellucidus Palynozone, $\mathrm{AOM}=$ amorphous organic matter 


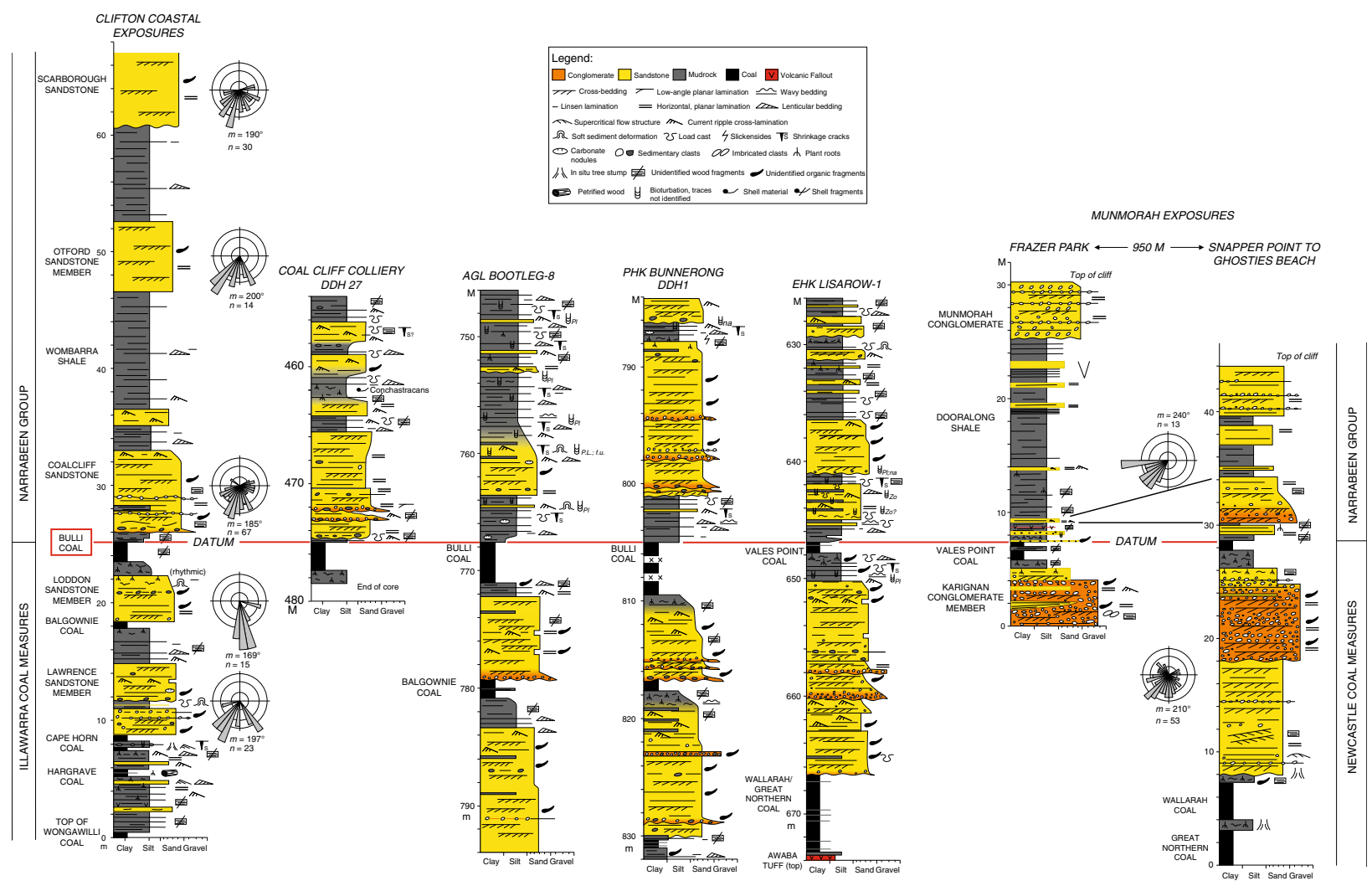

Fig. 3 Graphic logs of the Permo-Triassic boundary interval. Several outcrop sections and drillcores across the Sydney Basin (Fig. 1) are shown, illustrating continuity in sediment body character and stacking patterns (grain size, sandstone body thickness, sedimentary structures, facies relationships) and in sediment dispersal directions, across the putative EPE horizon (red line, which is the horizontal datum for the section). Key to symbols used is also shown

latest Permian. The uppermost coal seams across the basin are all associated with a typical Vertebraria- and Glossopteris-dominated fossil flora and represent the last evidence of coal-forming environments in eastern Australia for around 5-10 million years before the re-establishment of peat-forming ecosystems in the Middle Triassic ${ }^{41}$. The coal measures host a diverse palynoflora of which the pollen component is dominated by Protohaploxypinus and Striatopodocarpidites. Such taeniate (striate) bisaccate pollen were typically produced by glossopterids, although a few grains of these morphotypes may derive from other gymnosperm groups. Understorey components are dominated by the spores of ferns, sphenophytes, and lycophytes. Palynofacies data are available in Supplementary Table 3. This interval is assigned to the Wuchiapingian-Changhsingian D. parvithola Palynozone.

Glossopteris leaves were not detected above the uppermost coal seam in PHKB1 but possible Vertebraria roots were recorded within the mudstone at 4.24 and $4.39 \mathrm{~m}$ above this surface. There have been assertions that elements of the Glossopteris flora occur at an equivalent stratigraphic level elsewhere in the basin ${ }^{42}$, suggesting brief persistence of holdover glossopterid populations after the main 'extirpation event' (into the basal $P$. crenulata Palynozone). The 1-5-m-thick organic-rich shales overlying the Bulli Coal in the southern Sydney Basin have also yielded plant fossil assemblages marked by the first appearance of Lepidopteris callipteroides (Peltaspermales) and putative ginkgoaleans, voltzialean conifers, osmundaceous ferns, and isoetalean lycophytes ${ }^{43}$ within strata we assign to the $P$. crenulata Palynozone. Both taeniate and non-taeniate bisaccate pollen in this palynozone occur in low abundance (each $\sim 4 \%$ of the total palynomorph counts). This interval reflects rapid replacement of deciduous broad-leafed glossopterid-rich vegetation by communities dominated by pteridophytes and sparse sclerophyllous smallleafed gymnosperms.

Successive first appearances of key pollen taxa in the $50 \mathrm{~m}$ of consistently fluvial facies overlying the uppermost coal in PHKB1 (P. crenulata, P. microcorpus, L. pellucidus, and P. samoilovichii palynozones: Fig. 2; Supplementary Table 4) indicate rapid turnover in the vegetation through what we interpret to be the latest Changhsingian to Griesbachian (lower Induan) stages based on far-field palynological correlation with marine sections ${ }^{36}$.

First appearances of $L$. callipteroides and Voltziopsis sp. dispersed cuticle and macrofossils were recorded successively in PHKB1 at 783.2 and $779.6 \mathrm{~m}$ near the base of the Wombarra Shale corresponding to the upper $P$. crenulata Palynozone and the basal interval of the Protohaploxypinus microcorpus Palynozone, respectively. The latter zone has a palynofloral composition that is more or less the same as the preceding palynozone but with a significantly greater amount of non-taeniate pollen (Alisporites, Pteruchipollenites) as a proportion of total bisaccate pollen ( $\sim 55 \%$ non-taeniate below vs $\sim 69 \%$ above).

Above its first appearance at $745.6 \mathrm{~m}$, Lunatisporites represents the prevalent taeniate pollen type, reflecting the persistence of floras rich in voltzialean conifers (e.g. Voltziopsis africana). Other well-preserved taeniate bisaccate pollen taxa occur in small numbers (average $4 \%$ of total palynomorphs) through the first three palynozones above the EPE, but the absence of glossopterid macrofossils suggests that such grains were either reworked or produced by other gymnosperm groups. Pre-EPE palynomorphs typically show evidence of extensive authigenic sulphide corrosion in the Sydney Basin, but corroded grains above this datum are scarce (Supplementary Fig. 3), hence we interpret most postEPE taeniate bisaccate pollen to be non-reworked and of non- 
glossopterid (primarily conifer or peltasperm) affinity. The increase of non-taeniate forms, mainly Alisporites and Pteruchipollenites, reflects a corystosperm or coniferous component of the vegetation that became increasingly prevalent later in the Early Triassic.

The 778-587 $\mathrm{m}$ interval (Wombarra Shale to lower Bulgo Sandstone) is notably depauperate in plant macrofossils apart from a few dispersed cuticle fragments of Lepidopteris (peltasperm seed ferns), voltzialean conifers, and lycophyte leaves. Pleuromeian lycophyte megaspores and leaves occur sporadically through the entire Lower Triassic succession but become very abundant around 614 and $537 \mathrm{~m}$, respectively, in PHKB1 (both levels within the Bulgo Sandstone: Protohaploxypinus samoilovichii Palynozone) - an interval also marked by an increase in spinicaudatan carapaces (Fig. 2). The increase in abundance of pleuromeian megaspores (to levels $>50$ per $60 \mathrm{~g}$ sample) is matched by an increase in zonate trilete microspores (primarily Densoisporites) at $614 \mathrm{~m}$. The latter reach a maximum abundance of $54 \%$ of the total palynomorph count at $440 \mathrm{~m}$ (the uppermost sample of the P. samoilovichii Palynozone: Fig. 2). Throughout the succeeding Aratrisporites tenuispinosus Palynozone, trilete zonate spores decline, and monolete zonate spores (Aratrisporites, which also have probable pleuromeian affinities ${ }^{44}$ ) become the dominant spores, concurrent with the deposition of the Bald Hill Claystone above the Bulgo Sandstone. Dicroidium (corystosperm seed fern) leaves and dispersed cuticles become common only above $370 \mathrm{~m}$ within the Bald Hill Claystone near the base of the A. tenuispinosus Palynozone. Dicroidium persists throughout the remainder of the Triassic in eastern Australia, becoming a dominant component of coal-forming mire ecosystems in the Middle and Late Triassic ${ }^{45}$. Charcoal is present in minor quantities throughout the Lopingian to Lower Triassic successions with little change in abundance.

Geochemical proxies. Geochemical proxy data (Supplementary Table 5) are integrated with sedimentological and floral data sets to assess changes in climate and environment through the latest Permian and earliest Triassic. The Chemical Index of Alteration (CIA), which reflects the extent of alteration of feldspars to clays, denotes changes in conditions of weathering, with higher values indicating a higher intensity of chemical weathering. All data are derived from shales. The calculation is as follows: CIA $=\left[\mathrm{Al}_{2} \mathrm{O}_{3} /\right.$ $\left.\left(\mathrm{Al}_{2} \mathrm{O}_{3}+\mathrm{Na}_{2} \mathrm{O}+\mathrm{K}_{2} \mathrm{O}+\mathrm{CaO}^{*}\right)\right] \times 100$, where all oxides are in molar units and $\mathrm{CaO}^{*}$ represents the $\mathrm{CaO}$ in the silicate fraction of the rocks ${ }^{46,47}$. CIA values are relatively invariant, averaging 70 through the upper Wuchiapingian and most of the Changhsingian (Fig. 2). The interval 820-720 m encompasses a two-peaked excursion to values as high as 85.7 , with the highest values centring around the interval containing the uppermost coal and the loss of Glossopteris leaves in this core. CIA values then recover to a baseline of $\sim 75$ before rising to values that exceed 95 within the Bald Hill Claystone. The increases in CIA values around the level of the uppermost coal are indicative of a transient shift to warmer and more humid conditions that favoured increased chemical weathering. An increase in the intensity of chemical weathering across this interval is also indicated by an excursion in the ratio of kaolinite clays (dickite+halloysite+kaolinite) to illite (Fig. 2).

Throughout most of the succession, ratios of $\mathrm{Ni} / \mathrm{Al}\left(\times 10^{4}\right)$ values in mudrocks average 8.73 (Fig. 2). An excursion to 47.8 occurs within the Coal Cliff Sandstone, following the loss of the Glossopteris flora and the first appearances of several key pollen taxa (Fig. 2). Enhanced Ni concentrations have been noted across the same interval elsewhere in the southern Sydney Basin ${ }^{48}$. Trace element (TE)-total organic carbon (TOC) relationships indicate that the mudrocks analysed here formed mainly under dysoxic conditions, with redox-sensitive elements most likely residing in the detrital phase (see Supplementary Fig. 4). The boundary excursion in $\mathrm{Ni} / \mathrm{Al}$ occurs in mudrocks characterized by $\mathrm{TOC}<$ $0.15 \mathrm{wt} \%$, implying contributions from an outside source rather than reflecting an increase related to development of anoxic or euxinic conditions. A similar excursion in marine sections in South China was interpreted ${ }^{49}$ to record changes in ocean chemistry induced by Siberian Trap volcanism during emplacement of large economic concentrations of $\mathrm{Ni}$ in the Noril'sk region of Siberia just before and during the mass extinction interval ${ }^{50}$. The introduction of $\mathrm{Ni}$ into the marine environment was linked ${ }^{49}$ to a rapid expansion of the methanogenic archaeon Methanosarcina and the delivery of a large pulse of methane to the ocean. Although $\mathrm{Ni}$ is an essential micronutrient, it is toxic to plants at high concentrations, negatively impacting photosynthesis and respiration, inhibiting plant growth, and causing severe depletion in plant diversity ${ }^{51,52}$. Enhanced $\mathrm{Ni}$ concentrations in the Southern Sydney Basin around the time of plant extinction and replacement implicates Siberian Trap volcanism and the release of $\mathrm{Ni}$ as a potential contributing factor to the end Permian die-off of terrestrial vegetation.

The carbon isotope composition of bulk organic matter $\left(\delta^{13} \mathrm{C}_{\text {org }}\right)$ is relatively invariant, averaging $-24.1 \%$, through marine shelf and deltaic and coastal plain deposits in the lower part of the section (Fig. 2). Values become more variable in the succeeding part of the succession, with several negative excursions apparent between 610 and $801 \mathrm{~m}$. The interval containing the uppermost coal and overlying siltstones is marked by a negative excursion to values as low as $-27.5 \%$, which mirrors the spike in Ni. The overlying Wombarra Shale records an excursion to $\delta^{13} C_{\text {org }}$ values of $-29.5 \%$. Values continue to oscillate between end-member values of -22 and $-29.6 \%$ o through the Scarborough Sandstone and Stanwell Park Claystone (Fig. 2). The Bulgo Sandstone records a long-term decrease from -25 to $-28 \%$. The Bald Hill Claystone and Garie Formation are marked by an increase towards values of $-20 \%$. The increased variability and negative excursions in the $\delta^{13} \mathrm{C}_{\text {org }}$ record encompassing the loss of the Glossopteris flora and the subsequent turnover events imply additions of ${ }^{13} \mathrm{C}$-depleted carbon to the atmosphere and warming that have been documented previously in $\delta^{13} \mathrm{C}_{\text {org }}$ records from terrestrial sites in eastern Australia ${ }^{53}$ and elsewhere ${ }^{27}$.

Climate modelling. The seasonality of the central Sydney Basin in southeastern Gondwana (at $65^{\circ}-70^{\circ}$ south palaeolatitude ${ }^{54}$ ) at the end of the Permian, as revealed from Community Climate System Model (CCSM3) simulations, was characterized by warm wet summers and cold dry winters. The maximum modelled summer-to-winter temperature difference is about $20^{\circ} \mathrm{C}$ for the $4 \times$ the pre-industrial atmospheric $\mathrm{CO}_{2}$ concentration and $24^{\circ} \mathrm{C}$ for the $12.7 \times$ pre-industrial $\mathrm{CO}_{2}$ concentration (Fig. $4 \mathrm{a}, \mathrm{b}$ ), potentially representing the transition from pre-EPE to PTB conditions ${ }^{55}$. Under these simulations, proximity to the ocean led to high precipitation during the Gondwanan summer but markedly drier conditions during the Gondwanan winter. When considering a lower cloud optical depth parameterization in the $12.7 \times \mathrm{CO}_{2}$ simulation, owing to biophysical-climate feedbacks in a higher $\mathrm{CO}_{2}$ world ${ }^{56}$, average temperature increases but the seasonal temperature difference decreases to about $22^{\circ} \mathrm{C}$ (Fig. 4c). Significantly, under these parameters, mean winter temperatures are $9-10{ }^{\circ} \mathrm{C}$ above those for the standard $4 \times$ and $12.7 \times \mathrm{CO}_{2}$ simulations. This simulation might represent the Early Triassic hothouse climate ${ }^{55}$ conducive to enhanced weathering under which small-leafed sclerophyllous evergreen trees (e.g. voltzialean conifers) may have been selectively favoured over broad-leafed deciduous gymnosperms with thin cuticle (e.g. glossopterids) 
a

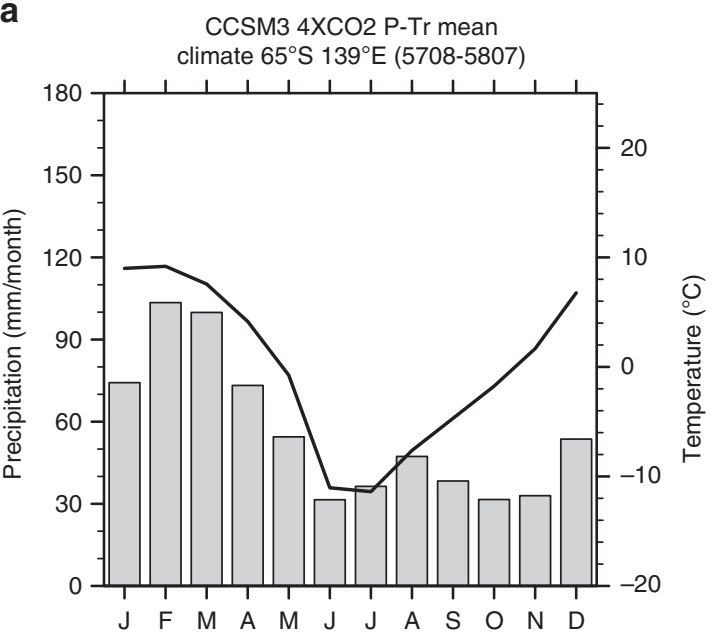

C

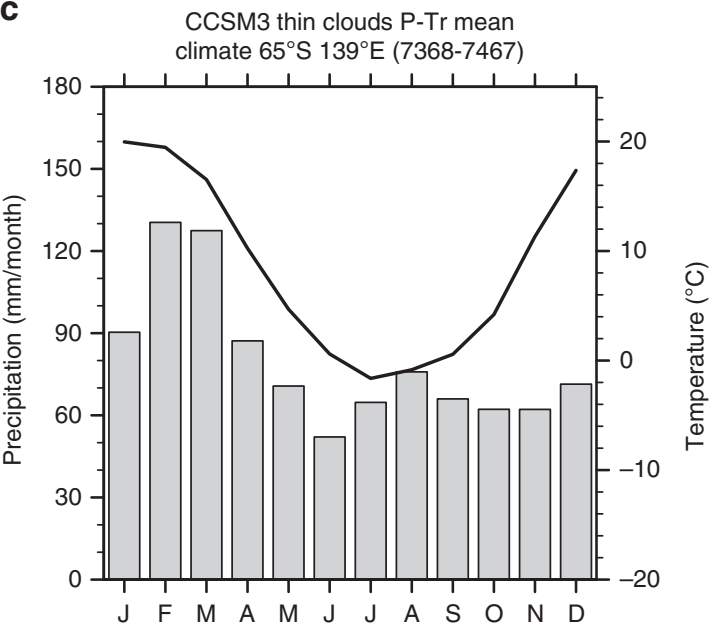

b

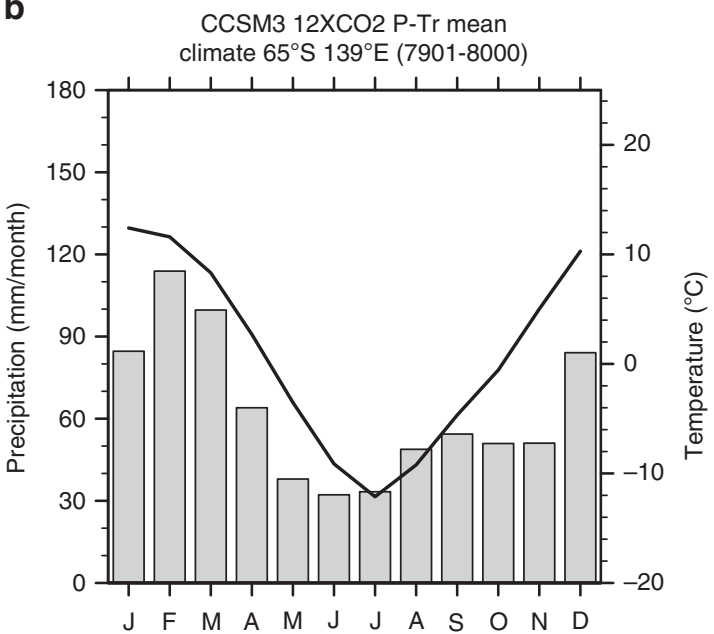

.

Fig. 4 Climatographs at the palaeo-location of the Sydney Basin. Based on simulations using the CCSM3 for the PTB ${ }^{55}$. a Simulation with $4 \times$ the preindustrial $\mathrm{CO}_{2}$, level, $\mathbf{b}$ simulation with $12.7 \times$ the pre-industrial $\mathrm{CO}_{2}$ level, and $\mathbf{c}$ simulation with $12.7 \times$ the pre-industrial $\mathrm{CO}_{2}$ level and a lower cloud optical depth

owing to more effective regulation of respiration and transpiration.

Palaeoenvironmental interpretation. In order to reconstruct the palaeo-landscape across the PTB, we acquired data on sandstone body thickness, grain size and composition, architecture, and palaeocurrent directions below and above the boundary from continuous surface exposures on both the southern (Illawarra Coast) and northern (Central Coast) limbs of the basin (Fig. 3). When comparing across several fluvial sediment bodies in the uppermost Illawarra Coal Measures and lowermost Narrabeen Group across the basin, we noted no upward increase in grain size or change in grain composition, no overall increase in sandstone body thickness, no perceptible change in sandstone body architecture (fluvial style), and no change in sediment dispersal directions (consistently southward) across the inferred continental EPE or PTB in any of the examined sections (Fig. 3). Furthermore, the facies immediately above the inferred continental EPE herein, both in outcrops and drillcores, are dominantly plant-fossil-bearing, grey mudrocks with mainly gradational boundaries (Fig. 3), and, in some cases, the lowermost erosionally based channel sandstone body is several metres above this level. Some localized accumulations of clay pellets and organic debris were noted above the uppermost $\operatorname{coal}^{57}$, but these rarely exceed a few $\mathrm{cm}$ in thickness and, moreover, are not dissimilar to clay-pellet granulestones lower in the Illawarra/Newcastle Coal Measures. All these features suggest that there was no exceptional erosional event or catastrophic physical degradation of the landscape at the level of the continental EPE. The predominance of grey mudrocks immediately above the Bulli Coal and equivalents across the basin, together with sporadic phytoplankton and AOM within these strata, suggests that the extinction interval was characterized by generally moist conditions even after the loss of peat-forming floras. Furthermore, the change in mudrock colour from dominantly grey to brown is gradual over 10 s to 100 s of metres of section above the level of the continental EPE, suggesting that a change to more freely drained alluvial landscapes was a progressive, long-term transition, rather than an abrupt change.

The simulated gradual climate changes in this region, even taking into consideration major injections of $\mathrm{CO}_{2}$ into the atmosphere, are consistent with the finding that sedimentation patterns did not change significantly over the investigated period. The simulated warmer and wetter conditions in the Sydney Basin area for the scenario potentially representing Early Triassic conditions can be explained by its proximity to the ocean. These results are in agreement with the higher CIA values for that time, indicating increased weathering relative to the late Permian. 


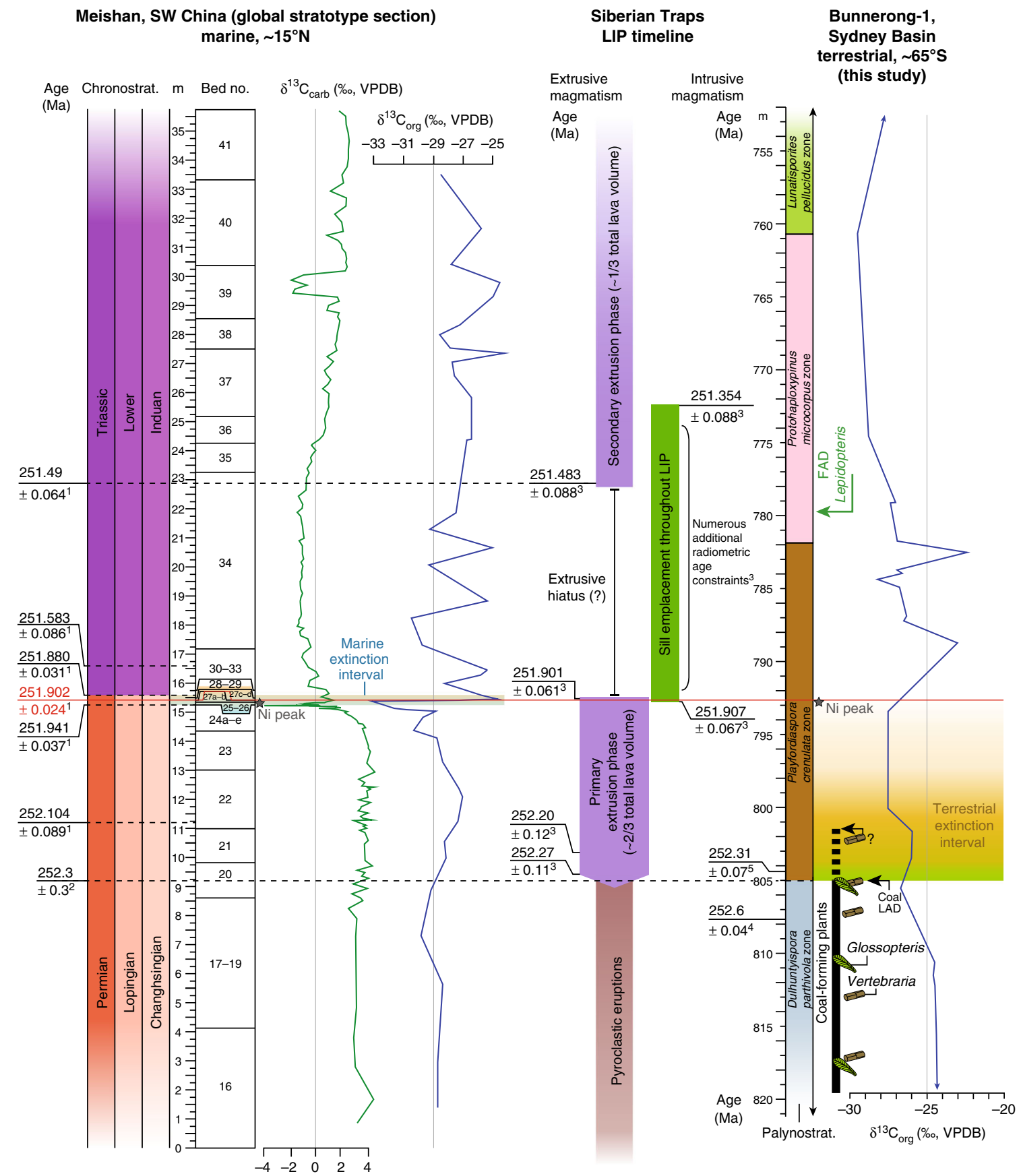

Fig. 5 Age correlations of the PTB and EPE. Correlations shown between the marine Permian-Triassic global stratotype section at Meishan, the terrestrial Sydney Basin succession, and the magmatic phases of the Siberian Traps Large Igneous Province. All absolute age uncertainties are at $2 \sigma$ level; ${ }^{1}=$ ref. $^{2}$, $2=$ ref. ${ }^{79}, 3=$ ref. $50,4=$ ref. $33,5=$ this study. $F A D=$ first appearance datum, $L A D=$ last appearance datum. Palaeolatitudes from ref. 54

In contrast to the consistency of sedimentary style and moderate climatic changes in this area, the plant macrofossil and palynological records indicate major shifts in plant group representation through this interval. Most notable is the abrupt collapse of glossopterid mire ecosystems at the inferred level of the continental EPE, with persistence of just a few survivors (e.g. a single Glossopteris species and Schizoneura gondwanensis) elsewhere in the basin for only a few metres above the boundary. Our data indicate that the primary palaeobotanical extinction event took place between 700 and 410 kyrs prior to the PTB, consistent with recent findings from China, and $\sim 370$ kyrs before the main marine extinction recorded in Meishan Bed 25 now dated at $251.941 \pm 0.037 \mathrm{Ma}^{2,58,59}$ (Fig. 5). This collapse was succeeded in the PHKB1 drillcore by a succession of relatively short-ranging plant communities (represented by the $P$. crenulata, $P$. microcorpus, $L$. pellucidus, and P. samoilovichii palynozones) variably dominated by peltasperm seed ferns, voltzialean conifers, and pleuromeian lycophytes through the latest Permian and earliest Triassic. Communities dominated by corystosperm (Umkomasiales) seed ferns did not become established until late in the Early Triassic (around 3 m.y. after the $\mathrm{EPE}^{60}$ : Fig. 2). The vegetation signal suggests the influence of far-field processes that overprinted the relatively stable regional (basin-wide) landscape conditions. The CIA, kaolinite/illite, and $\delta^{13} \mathrm{C}_{\text {org }}$ records indicate that the continental EPE was marked by a brief perturbation to warmer, more humid climate conditions that led to an increase in 
chemical weathering. Despite the high palaeolatitude $\left(65-70^{\circ} \mathrm{S}^{54}\right)$, there is no evidence for a short-lived PTB ice age as proposed recently ${ }^{61}$.

The last evidence of cold-water indices (P4 interval of the Late Palaeozoic Ice Age) around the Guadalupian-Lopingian boundary, disappearance of coal-forming mires near the close of the Permian, and intensification of redbed development together with very high CIA values in the late Early Triassic appear to reflect a very long-term trend towards warming over the 10 m.y. from the Wuchiapingian to mid-Olenekian. Moreover, this general pattern is reflected across the higher-latitude regions of the Southern Hemisphere, where glossopterid-dominated communities are consistently replaced around the close of the Permian by successive peltasperm-, voltzialean conifer-, pleuromeian lycophyte-, and corystosperm-dominated vegetation, with widespread representation of redbed successions 10 s to 100 s of metres above the level of the continental EPE ${ }^{62,63}$. Further, there may have been a rapid poleward progression in the replacement of these vegetation types with glossopterid coal-forming communities disappearing significantly earlier in northern Gondwana compared to southern palaeolatitudes ${ }^{64}$. The youngest examples of glossopterid leaves occur in strata of East Antarctica very close to the PTB ${ }^{65,66}$, suggesting that south polar regions acted as the final refugium for cool-climate, hygrophilous glossopterid gymnosperms ${ }^{67}$. Successive plant communities of the latest Permian and earliest Triassic probably initiated and collapsed upon reaching key environmental thresholds that were linked to temperature, the availability of moisture, the intensity of climatic seasonality, or levels of environmental contaminants (e.g. nickel or ozonedepleting halogens). Accurately dating the changes, quantifying these environmental tipping points, and defining the precise drivers of the global-scale environmental changes are key targets for future research, since they are relevant to understanding biotic responses to abrupt anthropogenic warming in the modern world.

Timing of the terrestrial end-Permian extinction event. The Permian-Triassic boundary GSSP at Meishan, China records two distinct pulses of marine faunal extinctions close to $251.941 \pm$ 0.037 and $251.880 \pm 0.031 \mathrm{Ma}^{2}$. These discrete events define the boundaries of a marine 'extinction interval' (sensu ref. ${ }^{17}$ ), which corresponds to stable carbon isotope excursions ${ }^{68,69}$ and a $\mathrm{Ni}$ abundance spike ${ }^{70}$. The age of this extinction interval is well correlated to the onset of massive magmatic intrusion of the Siberian Traps LIP ${ }^{50}$. In contrast, the floral collapse evident in the Sydney Basin is constrained by two U-Pb age high-precision determinations: $252.6 \pm 0.04$ and $252.31 \pm 0.07 \mathrm{Ma}$. As such, this terrestrial extinction interval, represented by a collapse of the Glossopteris flora, cessation of coal-forming conditions, and enhanced levels of phytoplankton and AOM, occurred $\sim 370$ kyrs prior to the onset of the marine extinction interval. The terrestrial extinction in the Sydney Basin is approximately concurrent with the onset of the primary extrusion phase of the Siberian Traps LIP $^{50}$ (Fig. 5). Siberian Traps volcanism is also implicated by severe fluctuations in stable carbon isotopes and an increase in $\mathrm{Ni}$ abundance during the terrestrial extinction interval $(P$. crenulata Palynozone; Fig. 5). This suggests that, despite a temporal decoupling of the terrestrial and marine biotic collapses, Siberian Traps magmatism was the likely trigger in both realms.

\section{Methods}

Geochronology. Zircon grains were separated from a dark grey mudrock (sample GA2167007) using standard techniques. The sample contains round grains that appear to be detrital zircon and sharply faceted grains that could be primary volcanic zircon. Only the sharply faceted grains were picked. Grains were annealed at $900{ }^{\circ} \mathrm{C}$ for $60 \mathrm{~h}$ in a muffle furnace. They were then mounted in epoxy and polished to expose their centres. A JEOL JSM-1300 scanning electron microscope coupled with a Gatan MiniCL were used to obtain cathodoluminescence photographs of grains (Supplementary Figure 2). Zircons were analysed by laser ablation inductively coupled plasma mass spectrometry (LA-ICPMS) with a ThermoElectron X-Series II quadrupole ICPMS and New Wave Research UP-213 Nd:YAG UV $(213 \mathrm{~nm})$ laser ablation system (Supplementary Table 1). Acquisition and calibration of U-Pb dates and a suite of high field strength elements (HFSE) and rare earth elements (REE) utilized in-house analytical protocols, standard materials, and data reduction software. A $25-\mu \mathrm{m}$-wide laser spot was used to ablate zircons. Fluence and pulse rates of $5 \mathrm{~J} / \mathrm{cm}^{2}$ and $10 \mathrm{~Hz}$, respectively, were used for $45 \mathrm{~s}(15 \mathrm{~s}$ gas blank, $30 \mathrm{~s}$ ablation) to excavate $\sim 25 \mu \mathrm{m}$ deep pits. A $1.2 \mathrm{l} / \mathrm{min}$ He gas stream carried the ablated material to the nebulizer flow of the plasma. Dwell times were as follows: $5 \mathrm{~ms}$ for $\mathrm{Si}$ and $\mathrm{Zr}, 200 \mathrm{~ms}$ for ${ }^{49} \mathrm{Ti}$ and ${ }^{207} \mathrm{~Pb}, 80 \mathrm{~ms}$ for ${ }^{206} \mathrm{~Pb}, 40 \mathrm{~ms}$ for ${ }^{202} \mathrm{Hg},{ }^{204} \mathrm{~Pb},{ }^{208} \mathrm{~Pb},{ }^{232} \mathrm{Th}$, and ${ }^{238} \mathrm{U}$ and $10 \mathrm{~ms}$ for all other HFSE and REE. Prior to each analysis, background count rates for each analyte were obtained and recorded. These were subsequently subtracted from raw count rates for each analyte. Pits that intersected glass or mineral inclusions within zircons were identified based on concentrations of $\mathrm{Ti}$ and $\mathrm{P}$. $\mathrm{U}-\mathrm{Pb}$ dates from these analyses are considered valid in cases where it is evident that $\mathrm{U} / \mathrm{Pb}$ ratios were not affected by inclusions. Those analyses that show evidence of contamination by common $\mathrm{Pb}$ (mass 204 being above a baseline) were rejected. To calculate concentrations of each analyte, background-subtracted count rates were normalized internally to ${ }^{29} \mathrm{Si}$ and calibrated relative to primary standards NIST SRM-610 and -612 glasses. Temperature calculations are based on the Ti-in-zircon thermometer (Supplementary Table 1). An average value in crustal rocks of 0.8 was used because of the lack of constraints on the activity of $\mathrm{TiO}_{2}$.

In determining $\mathrm{U}-\mathrm{Pb}$ and ${ }^{207} \mathrm{~Pb} /{ }^{206} \mathrm{~Pb}$ dates, the effects of instrumental fractionation of the background-subtracted ratios was corrected and dates were calibrated relative to regular measurements of zircon standards and reference materials. Time-dependent instrumental fractionation was monitored by including two analyses of the primary standard, the Plešovice zircon ${ }^{71}$, for every ten analyses of an unknown zircon. Results of measurements from the zircon standards Seiland (530 Ma, data available from Boise State University) and Zirconia (327 Ma, data available from Boise State University), treated as unknowns and measured once for every 10 analyses of an unknown zircon, were used to generate secondary corrections to ${ }^{206} \mathrm{~Pb} /{ }^{238} \mathrm{U}$ dates. A linear age bias of several percent, related to the ${ }^{206} \mathrm{~Pb}$ count rate, was evident. The secondary correction was used to mitigate matrix-dependent variations due to contrasting compositions and ablation characteristics between the Plešovice zircon and other standards (and unknowns)

All analyses include uncertainties related to radiogenic isotope ratio and age error propagation from counting statistics and background subtraction. First, Isoplot 3.0 (http://www.bgc.org/isoplot_etc/isoplot.html) was used to calculate a weighted mean ${ }^{206} \mathrm{~Pb} /{ }^{238} \mathrm{U}$ date from equivalent dates (probability of fit $>0.05$ ), using errors on individual ages that do not include uncertainties related to standard calibration. Subsequently, a standard calibration uncertainty is propagated into the error on the weighted mean age. This uncertainty $(1.2 \% ; 2 \sigma)$ equates to the local standard deviation of the polynomial fit to the interspersed primary standard measurements vs time. Errors on the dates are $2 \sigma$.

The CA-TIMS method was used to obtain $\mathrm{U}-\mathrm{Pb}$ ages from analyses on single zircon grains (Supplementary Table 2). Zircons for U-Pb age analysis were selected based on U-Pb dates from LA-ICPMS.

In preparation for analysis, zircon grains were placed in $3 \mathrm{ml}$ Teflon perfluoroalkoxy (PFA) beakers, loaded into $300 \mu \mathrm{l}$ Teflon PFA microcapsules, and placed in a large-capacity Parr vessel capable of holding 15 microcapsules. Zircon samples were placed in $120 \mu \mathrm{l}$ of $29 \mathrm{M}$ hydrofluoric acid (HF) for $12 \mathrm{~h}$ at $190^{\circ} \mathrm{C}$ and partially dissolved. Etched zircon was then returned to $3 \mathrm{ml}$ Teflon PFA beakers from which HF was decanted. Zircons were subsequently immersed in $3.5 \mathrm{M} \mathrm{HNO}_{3}$, placed in an ultrasonic bath for $1 \mathrm{~h}$, and then fluxed for an hour at $80{ }^{\circ} \mathrm{C}$ on a hotplate. Following this procedure, $\mathrm{HNO}_{3}$ was removed and zircon was rinsed twice in ultrapure $\mathrm{H}_{2} \mathrm{O}$ prior to reloading into $300 \mu \mathrm{l}$ Teflon PFA microcapsules that had been rinsed and fluxed in $6 \mathrm{M}$ hydrochloric acid $(\mathrm{HCl})$ during the sonification and washing process and spiked with the EARTHTIME mixed ${ }^{233} \mathrm{U}-{ }^{235} \mathrm{U}-{ }^{205} \mathrm{~Pb}$ tracer solution. Zircon was then dissolved in Parr vessels in a solution consisting of $120 \mu \mathrm{l}$ of $29 \mathrm{M} \mathrm{HF}$ and a trace of $3.5 \mathrm{M} \mathrm{HNO}_{3}$ for $48 \mathrm{~h}$ at $220^{\circ} \mathrm{C}$. Samples were dried to fluorides and re-dissolved in $6 \mathrm{M} \mathrm{HCl}$ overnight at $180^{\circ} \mathrm{C}$. An $\mathrm{HCl}$-based anion-exchange chromatographic procedure ${ }^{72}$ was used to separate $\mathrm{U}$ and $\mathrm{Pb}$ from the zircon matrix. $\mathrm{U}$ and $\mathrm{Pb}$ were then eluted together and dried with $2 \mu \mathrm{l}$ of $0.05 \mathrm{~N} \mathrm{H}_{3} \mathrm{PO}_{4}$

In preparation for analysis, $\mathrm{Pb}$ and $\mathrm{U}$ were loaded on a single outgassed $\mathrm{Re}$ filament in $5 \mu \mathrm{l}$ of a silica-gel/phosphoric acid mixture ${ }^{73}$. $\mathrm{U}$ and $\mathrm{Pb}$ isotopic measurements were determined using a GV Isoprobe-T multicollector thermal ionization mass spectrometer equipped with an ion-counting Daly detector. Measurement of $\mathrm{Pb}$ isotopes was carried out by peak-jumping all isotopes on the Daly detector for 160 cycles. Results were corrected for $0.16 \pm 0.03 \% /$ a.m.u. ( $1 \sigma$ error) mass fractionation. Transitory isobaric interferences brought about by the presence of high-molecular weight organics, particularly on ${ }^{204} \mathrm{~Pb}$ and ${ }^{207} \mathrm{~Pb}$, disappeared within approximately 30 cycles as ionization efficiency averaged 104 $\mathrm{cps} / \mathrm{pg}$ of each $\mathrm{Pb}$ isotope. Analysis of NBS982 was used to determine linearity (to $\geq 1.4 \times 106 \mathrm{cps}$ ) and the accompanying deadtime correction of the Daly detector. Uranium was analysed as $\mathrm{UO}^{2+}$ ions in static Faraday mode on 1012-ohm resistors for 300 cycles and corrected for isobaric interference of ${ }^{233} \mathrm{U}^{18} \mathrm{O}^{16} \mathrm{O}$ on 
${ }^{235} \mathrm{U}^{16} \mathrm{O}^{16} \mathrm{O}$ with an ${ }^{18} \mathrm{O} /{ }^{16} \mathrm{O}$ of 0.00206 . For each $\mathrm{U}$ isotope, ionization efficiency averaged $20 \mathrm{mV} / \mathrm{ng}$. The known ${ }^{233} \mathrm{U} / 235 \mathrm{U}$ ratio of the EARTHTIME tracer solution was used to correct for $\mathrm{U}$ mass fractionation.

Published algorithms, EARTHTIME ET535 tracer solution ${ }^{74}$ with calibration of ${ }^{235} \mathrm{U} / 205 \mathrm{~Pb}=100.233,{ }^{233} \mathrm{U} / 235 \mathrm{U}=0.99506$, and ${ }^{205} \mathrm{~Pb} / 204 \mathrm{~Pb}=11268$, and $\mathrm{U}$ decay constants (Supplementary Table 2) were used to calculate CA-TIMS U-Pb dates and uncertainties. $\mathrm{DTh} / \mathrm{U}=0.20 \pm 0.05(1 \sigma)$ and published algorithms (Supplementary Table 2) were used to correct ${ }^{206} \mathrm{~Pb} /{ }^{238} \mathrm{U}$ ratios and dates for initial ${ }^{230} \mathrm{Th}$ disequilibrium. This resulted in an increase of $\sim 0.09 \mathrm{Ma}$ in the ${ }^{206} \mathrm{~Pb} / 238 \mathrm{U}$ dates. All common $\mathrm{Pb}$ in analyses was attributed to laboratory blank and subtracted based on the measured laboratory $\mathrm{Pb}$ isotopic composition and associated uncertainty. U blanks are estimated at $0.013 \pm 0.009 \mathrm{pg}(1 \sigma)$.

Isoplot 3.0 was used to calculate weighted mean ${ }^{206 \mathrm{~Pb} / 238} \mathrm{U}$ dates from equivalent dates (probability of fit $>0.05$ ). Errors on the weighted mean dates are $\pm x / y / z$. In this equation, $x$ is the internal error based on analytical uncertainties only, including subtraction of tracer solution, counting statistics, and blank and initial common $\mathrm{Pb}$ subtraction. The $y$ factor includes the tracer calibration uncertainty propagated in quadrature, whereas $z$ includes the ${ }^{238} \mathrm{U}$ decay constant uncertainty propagated in quadrature. When comparing our dates with ${ }^{206} \mathrm{~Pb} /{ }^{238} \mathrm{U}$ dates from other laboratories that used the same EARTHTIME tracer solution or a tracer solution that was crosscalibrated using EARTHTIME gravimetric standards, internal errors should be considered. In addition, errors such as the uncertainty in the tracer calibration should be considered when comparing our dates with those derived from other geochronological methods (e.g. LA- ICPMS) that use the U-Pb decay scheme. Errors including uncertainties in the tracer calibration and ${ }^{238} \mathrm{U}$ decay constant (Supplementary Table 2) should also be considered when comparing our dates with those derived from other decay schemes (e.g. ${ }^{40} \mathrm{Ar} /{ }^{39} \mathrm{Ar},{ }^{187} \mathrm{Re}-{ }^{187} \mathrm{Os}$ ). Errors for weighted mean dates and dates from individual grains are given at $2 \sigma$.

Nineteen grains from 2,167,007 analysed by LA-ICPMS yielded dates between $426 \pm 17$ and $243 \pm 10 \mathrm{Ma}$. The youngest nine dates are equivalent with a weighted mean of $252 \pm 5 \mathrm{Ma}(\mathrm{MSWD}=1.9$, probability of fit $=0.06$ ). Seven of the grains yielding young dates were removed from the mounts and analysed by CA-TIMS. Two of the grains were broken into two fragments that were analysed separately. The nine dates (Supplementary Figure 1) are equivalent with a weighted mean of $252.31 \pm 0.07 /$ $0.14 / 0.30 \mathrm{Ma}(\mathrm{MSWD}=1.0$, probability of fit $=0.48$ ). Despite the large population of detrital zircon in this sample as indicated by $>260$ Ma LA-ICPMS dates and round grains, the CA-TIMS weighted mean date is interpreted as the depositional age because a relatively large number of grains yielded equivalent dates.

Palynology. Fifty-two samples were chosen from well core sediment samples of PKHB1 for palynological processing and slide preparation. These were digested using $\mathrm{HCl}$ and $\mathrm{HF}$. For palynofacies, kerogen slides were produced for all samples. For palynomorph counts, 44 samples were oxidized with Schulze's Solution, then sieved at $10 \mu \mathrm{m}$. All slides are provided with prefix ' $S$ ' and stored at the Department of Palaeobiology, Naturhistoriska riksmuseet, Stockholm, Sweden. Palynomorph images were collected on a Zeiss Axioskop 2 Plus transmitted light microscope, and images were taken on a Zeiss AxioCam MRc camera.

Palynofacies data were compiled from counts of 500 individual grains (minimum grain diameter $=5 \mu \mathrm{m}$ ). The following palynofacies categories were included in the counts (following the classification of Tyson, $1995^{75}$ ): (1) plant spores, (2) pollen, (3) phytoplankton, (4) opaque phytoclasts, (5) tracheids/rays, (6) other translucent phytoclasts, (7) cuticles/membranous tissues, (8) particulate AOM, (9) fungal debris, and (10) resin. Palynomorph counts consisted of 250 grains, but 6 of the samples counted for palynomorphs failed to meet the total specimen count (S014097, S014099, S014100, S014105, S014116, and S014141). Where present, index spore-pollen taxa were counted from both sieved and kerogen slides. Biostratigraphic correlations were based on regional zonation schemes ${ }^{36,37,76}$. The details for all samples examined in this study are summarized in Supplementary Tables 3 and 4.

A qualitative taphonomic assessment of spores and pollen was included to demonstrate the degree of reworking within this section. In this case, we applied the preservation quality of pre-EPE spores and pollen fossils vs those from postEPE strata. Pre-EPE specimens typically have a high degree of corrosion. The style of degradation is characteristic of authigenic sulphide mineralization (e.g., pyrite, marcasite). As authigenic sulphides have been shown to form within organic-rich reducing conditions during or soon after sedimentation, this diagenetic effect on pre-EPE specimens was likely (pene)contemporaneous. Thus this degradation pattern serves as a proxy for specimens that have been reworked from pre-EPE sediments into overlying strata. This effect is not likely a local phenomenon as it has been noted in other wells from the Sydney Basin (Coalcliff Colliery DDH 27, EHK Lisarow-1; Fig. 3). However, the occurrence of such degraded grains in postEPE strata is negligible, indicating only minor reworking. We present the photographic evidence in Supplemental Fig. 3 to support this interpretation.

Geochemistry. Elemental concentrations in shales and mudrocks (powdered) were determined by both X-ray fluorescence (XRF) and ICP-atomic emission spectroscopy (AES). XRF analyses were carried out on pressed powders using a Bruker Tracer 5i equipped with an Rh X-ray tube at the University of Nebraska-Lincoln. Each sample was analysed at low-energy (major elements) and high-energy (TEs) conditions for count times of 15 and $60 \mathrm{~s}$, respectively. Low-energy analyses were undertaken at $15 \mathrm{kV}$ with no filter, whereas high-energy analyses were undertaken at $40 \mathrm{kV}$ with a Ti25um Al 300 filter. ICP-AES measurements were conducted by American Assay Laboratories on $0.5 \mathrm{~g}$ samples using a five-acid digestion. CIA was calculated using $\mathrm{Al}, \mathrm{Ca}, \mathrm{K}, \mathrm{Na}$, and $\mathrm{P}$ concentrations by ICP-AES and Si concentrations by XRF (Supplementary Table 5). Ni/Al ratios shown in Fig. 2 were determined via ICP-AES.

The stable carbon isotope composition of bulk organic matter $\left(\delta^{13} \mathrm{C}_{\mathrm{org}}\right)$ was determined on splits of samples used for palynological analysis (Supplementary Table 3). TOC, total nitrogen, and $\delta^{15} \mathrm{~N}$ values were measured simultaneously but not reported here. In preparation for analysis, samples were powdered. Up to $500 \mathrm{mg}$ of sample was placed in a $50 \mathrm{ml}$ centrifuge tube and reacted overnight with $1 \mathrm{~N} \mathrm{HCl}$ at room temperature to remove carbonate mineral phases and rinsed three times with ultra-pure water. In each case, the supernatant was separated by centrifugation (3000 RPM for $5 \mathrm{~min}$ ) and discarded. Samples were subsequently dried and crushed using an agate mortar and pestle. Sample splits were analysed using a Costech Elemental Analyser connected to a Thermo Finnigan MAT 253 stable-isotope gas-ratio mass spectrometer at the Keck-NSF Palaeoenvironmental and Environmental Laboratory at the University of Kansas. Carbon isotope compositions are reported in per mil (\%) relative to the Vienna Peedee Belemnite (V-PDB) standard). Montana Soil (NIST Ref Mat. 2711) and a calibrated yeast standard were used to monitor quality control, with compiled results over 2 years showing analytical error to be within $\pm 0.22 \%$ for $\delta^{13} \mathrm{C}$.

Palaeoclimate modelling. The climate transition across the PTB was simulated by three time-slice experiments with the global Community Climate System Model version $3(\mathrm{CCSM} 3)^{77}$. The atmosphere was resolved by a horizontal spectral T31 grid $\left(\sim 3.75^{\circ} \times 3.75^{\circ}\right)$ and by 26 unevenly spaced terrain-following vertical layers, while the ocean had a nominal $3^{\circ}$ horizontal grid and 25 vertical layers with higher resolution near the surface. The boundary conditions consisted of a palaeoinsolation of $1338 \mathrm{~W} / \mathrm{m}^{2}$ (which is $\sim 2.1 \%$ lower than the present value), palaeoorbital settings (eccentricity of $0^{\circ}$, obliquity of $23.5^{\circ}$ ), palaeogeography, and palaeoland surface conditions ${ }^{55}$

Three climate simulations have been carried out to assess the environmental changes across the PTB. For a baseline scenario for the time prior to the flood basalt volcanism, greenhouse gas levels of four times the pre-industrial level of 280 ppmv $\left(4 \times \mathrm{CO}_{2}\right)$ were used ${ }^{55}$. The second climate scenario assumed elevated atmospheric greenhouse levels of $12.7 \times \mathrm{CO}_{2}$ for near-PTB conditions. In addition, an Early Triassic hothouse climate sensitivity experiment at $12.7 \times \mathrm{CO}_{2}$ considered a reduced cloud optical thickness in response to changes in the cloud droplet radii and concentration ${ }^{55,56}$. All simulations were equilibrated into quasi-steady state (with $\sim 5500-8000$ years of integration).

Code availability. The climate model description and code are available at http:// www.cesm.ucar.edu/models/ccsm3.0/

Reporting summary. Further information on experimental design is available in the Nature Research Reporting Summary linked to this article.

\section{Data availability}

The authors declare that all data supporting the findings of this study are available within the paper and its supplementary information files. Palynological slides used in this study are held in the collections of the Swedish Museum of Natural History (NRM), Stockholm under the registration codes SMNH S014095-014149. Core samples and plant fossil records are held in the W.B. Clarke Geoscience Centre drillcore library, Londonderry, New South Wales, Australia, with duplicate photographic records held at NRM. A reporting summary for this article is available as a supplementary information file.

Received: 12 June 2018 Accepted: 5 December 2018 Published online: 23 January 2019

\section{References}

1. Erwin, D. H. Extinction: How Life on Earth Nearly Ended 250 Million Years Ago (Princeton University Press, Princeton, NJ, 2006).

2. Burgess, S. D., Bowring, S. A. \& Shen, S.-Z. High-precision timeline for Earth's most severe extinction. Proc. Natl. Acad. Sci. 111, 3316-3321 (2014).

3. Renne, P. R., Zichao, Z., Richards, M. A., Black, M. T. \& Basu, A. R. Synchrony and causal relations between Permian-Triassic boundary crisis and Siberian flood volcanism. Science 269, 1414-1416 (1995).

4. Kamo, S. L. et al. Rapid eruption of Siberian flood-volcanic rocks and evidence for coincidence with the Permian-Triassic boundary and mass extinction at 251 Ma. Earth. Planet. Sci. Lett. 214, 75-91 (2003).

5. Sobolev, S. V. et al. Linking mantle plumes, large igneous provinces and environmental catastrophes. Nature 477, 312-316 (2011). 
6. Payne, J. L. \& Kump, L. R. Evidence for recurrent Early Triassic massive volcanism from quantitative interpretation of carbon isotope fluctuations. Earth. Planet. Sci. Lett. 256, 264-277 (2007).

7. Grasby, S. E., Sanei, H. \& Beauchamp, B. Catastrophic dispersion of coal fly ash into oceans during the latest Permian extinction. Nat. Geosci. 4, 104-107 (2011).

8. Clapham, M. E. \& Payne, J. L. Acidification, anoxia, and extinction: a multiple logistic regression analysis of extinction selectivity during the Middle and Late Permian. Geology 39, 1059-1062 (2011).

9. Kump, L. R. in The Atmosphere-History. Treatise on Geochemistry (ed. Farquhar, J.) 269-280 (Elsevier, Oxford, 2014).

10. Black, B. A., Lamarque, J.-F., Shields, C. A., Elkins-Tanton, L. T. \& Kiehl, J. T. Acid rain and ozone depletion from pulsed Siberian Traps magmatism. Geology 42, 67-70 (2014).

11. Algeo, T. J., Chen, Z. Q., Fraiser, M. L. \& Twitchett, R. J. 2011, Terrestrialmarine teleconnections in the collapse and rebuilding of Early Triassic marine ecosystems. Palaeogeogr. Palaeoclimatol. Palaeoecol. 308, 1-11 (2011).

12. Stanley, S. M. \& Yang, X. A double mass extinction at the end of the Paleozoic era. Science 266, 1340-1344 (1994).

13. Isozaki, Y., Kawahata, H. \& Minoshima, K. The Capitanian (Permian) Kamura cooling event: the beginning of the Paleozoic-Mesozoic transition. Palaeoworld 16, 16-30 (2007).

14. Clapham, M. E., Shen, S. Z. \& Bottjer, D. J. The double mass extinction revisited: re-assessing the severity, selectivity, and paleobiogeographic pattern of the endGuadalupian biotic crisis (Late Permian). Paleobiol 35, 32-50 (2009).

15. Jiang, H. S., Joachimski, M. M., Wignall, P. B., Zhang, M. H. \& Lai, X. L. A delayed end-Permian extinction in deep-water locations and its relationship to temperature trends (Bianyang, Guizhou Province, South China). Palaeogeogr. Palaeoclimatol. Palaeoecol. 440, 690-695 (2015).

16. Yin, H. F., Feng, Q. L., Lai, X. L., Baud, A. \& Tong, J. N. The protracted Permo-Triassic crisis and the multi-episode extinction around the PermianTriassic boundary. Glob. Planet. Change 55, 1-20 (2007).

17. Song, H., Wignall, P. B., Tong, J. \& Yin, H. Two pulses of extinction during the Permian-Triassic crisis. Nat. Geosci. 6, 52-56 (2013).

18. Benton, M. J. \& Newell, A. J. Impacts of global warming on Permo-Triassic terrestrial ecosystems. Gondwana Res. 25, 1308-1337 (2014).

19. Smith, R. M. H. \& Botha-Brink, J. Anatomy of a mass extinction: sedimentological and taphonomic evidence for drought-induced die-offs at the Permo-Triassic boundary in the main Karoo Basin, South Africa. Palaeogeogr. Palaeoclimatol. Palaeoecol. 396, 99-118 (2014).

20. MacLeod, K. G., Quinton, P. C. \& Bassett, D. J. 2017. Warming and increased aridity during the earliest Triassic in the Karoo Basin, South Africa. Geology 45, 483-486 (2017).

21. Li, J. W., Gastaldo, R. A., Neveling, J. \& Geissman, J. W. Siltstones across the Daptocephalus (Dicynodon) and Lystrosaurus assemblage zones, Karoo Basin, South Africa, show no evidence for aridification. J. Sed. Res. 87, 653-671 (2017).

22. Smith, R. M. H. Changing fluvial environments across the Permo-Triassic boundary in the Karoo Basin, South Africa and possible causes of tetrapod extinctions. Palaeogeogr. Palaeoclimatol. Palaeoecol. 117, 81-104 (1995).

23. Ward, P. D., Montgomery, D. R. \& Smith, R. Altered river morphology in South Africa related to the Permian-Triassic extinction. Science 289, 1740-1743 (2000).

24. Michaelsen, P. Mass extinction of peat-forming plants and the effect on fluvial styles across the Permian-Triassic boundary, northern Bowen Basin, Australia. Palaeogeogr. Palaeoclimatol. Palaeoecol. 179, 173-188 (2002).

25. Davies, C., Allen, M. B., Busboy, M. M. \& Safonova, I. Deposition in the Kuznetsk Basin, Siberia: insights into the Permian-Triassic transition and the Mesozoic evolution of central Asia. Palaeogeogr. Palaeoclimatol. Palaeoecol. 295, 307-322 (2010)

26. Yu, J. et al. Terrestrial events across the Permian-Triassic boundary along the Yunnan-Guizhou border, SW China. Glob. Planet. Change 55, 193-208 (2007).

27. Cui, Y. et al. Carbon cycle perturbation expressed in terrestrial PermianTriassic Boundary sections in South China. Glob. Planet. Change 148, 272-285 (2017).

28. Bercovici, A., Cui, Y., Forel, M.-B., Yu, J. \& Vajda, V. Terrestrial paleoenvironment characterization across the Permian-Triassic boundary in South China. J. Asian Earth Sci. 98, 225-246 (2015).

29. Bercovici, A. \& Vajda, V. 2016. Terrestrial Permian-Triassic boundary sections in South China. Glob. Planet. Change 143, 31-33 (2016).

30. Herbert, C. \& Helby, R. R. (eds). A Guide to the Sydney Basin. Geological Survey of New South Wales - Bulletin 26 (D. West, Govt. Printer, Sydney, 1980).

31. Foster, C. B., Logan, G. A. \& Summons, R. E. The Permian-Triassic boundary in Australia: where is it and how is it expressed? Proc. R. Soc. Vict. 110, 247-266 (1998).
32. Helby, R. Review of Late Permian and Triassic palynology of New South Wales. Spec. Publ. Geol. Soc. Aust. 4, 141-155 (1973).

33. Metcalfe, I., Crowley, J. L., Nicoll, R. S. \& Schmitz, M. High-precision U-Pb CA-TIMS calibration of Middle Permian to Lower Triassic sequences, mass extinction and extreme climate-change in eastern Australian Gondwana. Gondwana Res. 28, 61-81 (2015).

34. Laurie, J. R. et al. Calibrating the middle and late Permian palynostratigraphy of Australia to the geologic time scale via U-Pb zircon CA-IDTIMS dating. Aust. J. Earth Sci. 63, 701-730 (2016).

35. Huyskens, M. H. Improving Precision and Accuracy of U-Pb Geochronology with Application to the Permian Period. Unpublished $\mathrm{PhD}$ dissertation, Australian National Univ. (2014).

36. Helby, R., Morgan, R. \& Partridge, A. D. A palynological zonation of the Australian Mesozoic. Assoc. Australas. Palaeontol. Mem. 4, 1-94 (1987).

37. Price, P. L. in The Surat and Bowen Basins, South-east Queensland. QLD Minerals and Energy Review Series (ed. Green, P. M.) 137-178 (QLD Dept. Mines \& Energy, Brisbane, 1997)

38. Fielding, C. R. et al. Stratigraphic imprint of the Late Paleozoic Ice Age in eastern Australia: a record of alternating glacial and nonglacial climate regime. J. Geol. Soc. Lond. 165, 129-140 (2008).

39. Bamberry, W. J. Stratigraphy and Sedimentology of the Late Permian Illawarra Coal Measures, Southern Sydney Basin, New South Wales. Unpublished PhD dissertation, Univ. Wollongong (1991).

40. Bamberry, W. J., Hutton, A. C. \& Jones, B. G. in Geology of Deltas (eds Oti, M. N. \& Postma, G.) 153-166 (Balkema, Rotterdam, 1995).

41. Retallack, G. J., Veevers, J. J. \& Morante, R. 1996. Global coal gap between Permian-Triassic extinction and Middle Triassic recovery of peat-forming plants. Geol. Soc. Am. Bull. 108, 195-207 (1996).

42. Dun, W. S. Sydney Harbour Collieries Limited, Sydney: section of strata sunk through at the Birthday Shaft. Annu. Rep. Dept. Mines N.S.W. For. 1907, 154-161 (1908).

43. Retallack, G. J. Lepidopteris callipteroides, an earliest Triassic seed fern of the Sydney Basin, southeastern Australia. Alcheringa 26, 475-500 (2002).

44. Balme, B. E. Fossil in situ spores and pollen grains: an annotated catalogue. Rev. Palaeobot. Palynol. 87, 81-323 (1995).

45. Balme, B. E., Kershaw, A. P. \& Webb, J. A. in Geology of Australian Coal Basins (eds Ward, C. R., Harrington, H. J., Mallett, C. W. \& Beeston, J. W.) 41-62 (Geological Society of Australia, Coal Geology Group, Sydney, 1995).

46. Nesbitt, H. W. \& Young, G. M. Early Proterozoic climates and plate motions inferred from major element chemistry of lutites. Nature 299, 715-717 (1982).

47. McLennan, S. M., Hemming, S., McDanniel, D. K. \& Hanson, G. N. in Processes Controlling the Composition of Clastic Sediments (eds Johnsson, M. J. \& Basu, A.) 21-40 (GeoScienceWorld, McLean, VA, 1993).

48. Williams, M. L., Jones, B. G. \& Carr, P. F. The interplay between massive volcanism and the local environment: Geochemistry of the Late Permian mass extinction across the Sydney Basin, Australia. Gondwana Res. 51, 149-169 (2017).

49. Rothman, D. H. et al. Methanogenic burst in the end-Permian carbon cycle. Proc. Nat. Acad. Sci. 111, 5462-5467 (2014).

50. Burgess, S. D. \& Bowring, S. A. High-precision geochronology confirms voluminous magmatism before, during, and after Earth's most severe extinction. Sci. Adv. 1, e1500470 (2015).

51. Foy, C. D., Chaney, R. L. \& White, M. C. The physiology of metal toxicity in plants. Ann. Rev. Plant Physiol. 29, 511-566 (1978)

52. Chen, C., Huang, D. \& Liu, J. Functions and toxicity of nickel in plants: recent advances and future prospects. Clean 37, 304-313 (2009).

53. Retallack, G. J. et al. Multiple Early Triassic greenhouse crises impeded recovery from Late Permian mass extinction. Palaeogeogr. Palaeoclimatol. Palaeoecol. 308, 233-251 (2011).

54. Frank, T. D., Shultis, A. I. \& Fielding, C. R. 2015. Acme and demise of the late Palaeozoic ice age: a view from the southeastern margin of Gondwana. Palaeogeogr. Palaeoclimatol. Palaeoecol. 418, 176-192 (2015).

55. Winguth, A. M. E., Shields, C. \& Winguth, C. Transition into a hothouse world at the Permian-Triassic boundary - A model study. Palaeogeogr. Palaeoclimatol. Palaeoecol. 440, 316-327 (2015).

56. Kump, L. R. \& Pollard, D. Amplification of Cretaceous warmth by biological cloud feedbacks. Science 320, 195 (2008).

57. Retallack, G. J. Earliest Triassic claystone breccias and soil-erosion crisis. J. Sed. Res 75, 679-695 (2005).

58. Zhang, $H$. et al. The terrestrial end-Permian mass extinction in South China Palaeogeogr. Palaeoclimatol. Palaeoecol. 448, 108-124 (2016).

59. $\mathrm{Xu}, \mathrm{G}$. Z. et al. High-resolution clay mineral and major elemental characterization of a Permian-Triassic terrestrial succession in southwestern China: diagenetic and paleoclimatic/paleoenvironmental significance. Palaeogeogr. Palaeoclimatol. Palaeoecol. 481, 77-93 (2017).

60. Retallack, G. J. in A Guide to the Sydney Basin. Geological. Survey of New . South.Wales. - Bulletin 26 (eds Herbert, C. \& Helby, R. J.) 384-430 (D. West, Govt. Printer, Sydney, 1980). 
61. Baresel, B. et al. Timing of global regression and microbial bloom linked with the Permian-Triassic boundary mass extinction: implications for driving mechanisms. Sci. Rep. 7, 43630 (2017).

62. McLoughlin, S. \& Drinnan, A. N. Fluvial sedimentology and revised stratigraphy of the Triassic Flagstone Bench Formation, northern Prince Charles Mountains, East Antarctica. Geol. Mag. 134, 781-806 (1997).

63. Collinson, J. W., Hammer, W. R., Askin, R. A. \& Elliot, D. H. PermianTriassic boundary in the central Transantarctic Mountains, Antarctica. Bull. Geol. Soc. Am. 118, 747-763 (2006).

64. McLoughlin, S., Lindström, S. \& Drinnan, A. N. Gondwanan floristic and sedimentological trends during the Permian-Triassic transition: new evidence from the Amery Group, northern Prince Charles Mountains, East Antarctica. Antarct. Sci. 9, 281-298 (1997).

65. McManus, H. A., Taylor, E. L., Taylor, T. N. \& Collinson, J. W. A petrified Glossopteris flora from Collinson Ridge, central Transantarctic Mountains: Late Permian or Early Triassic? Rev. Palaeobot. Palynol. 120, 233-246 (2002).

66. Elliot, D. H., Fanning, C. M., Isbell, J. L. \& Hulett, S. R. W. The Permo-Triassic Gondwana sequence, central Transantarctic Mountains, Antarctica: zircon geochronology, provenance, and basin evolution. Geosphere 13, 155-178 (2017).

67. Bomfleur, B., Blomenkemper, P., Kerp, H. \& McLoughlin, S. in Transformative Paleobotany: Papers to Commemorate the Life and Legacy of Thomas N. Taylor (eds Krings, M., Harper, C. J., Cúneo, N. R., \& Rothwell, G. W.) 593-611 (Academic Press, Elsevier, London, 2018).

68. Cao, C., Wang, W. \& Jin, Y. Carbon isotope excursions across the PermianTriassic boundary in the Meishan section, Zhejiang Province, China. Chin. Sci. Bull. 47, 1125-1129 (2002).

69. Cao, C. et al. Biogeochemical evidence for euxinic oceans and ecological disturbance presaging the end-Permian mass extinction event. Earth Planet. Sci. Lett. 281, 188-201 (2009).

70. Kaiho, K. et al. End-Permian catastrophe by a bolide impact: evidence of a gigantic release of sulfur from the mantle. Geology 29, 815-818 (2001).

71. Sláma, J. et al. Plešovice zircon-a new natural reference material for $\mathrm{U}-\mathrm{Pb}$ and Hf isotopic microanalysis. Chem. Geol. 249, 1-35 (2008).

72. Krogh, T. E. A low contamination method for hydrothermal decomposition of zircon and extraction of $\mathrm{U}$ and $\mathrm{Pb}$ for isotopic age determination. Geochim. Cosmochim. Acta 37, 485-494 (1973).

73. Gerstenberger, H. \& Haase, G. A highly effective emitter substance for mass spectrometric $\mathrm{Pb}$ isotope ratio determinations. Chem. Geol. 136, 309-312 (1997).

74. Condon, D. J., Schoene, B., McLean, N. M., Bowring, S. A. \& Parrish, R. Metrology and traceability of $\mathrm{U}-\mathrm{Pb}$ isotope dilution geochronology (EARTHTIME Tracer Calibration Part I). Geochim. Cosmochim. Acta 164, 464-480 (2015).

75. Tyson, R. V. Sedimentary Organic Matter: Organic Facies and Palynofacies (Chapman \& Hall, London, 1995).

76. Foster, C. B. Spore-pollen assemblages of the Bowen Basin, Queensland (Australia): their relationship to the Permian/Triassic boundary. Rev. Palaeobot. Palynol. 36, 165-183 (1982).

77. Collins, W. D. et al. The Community Climate System Model Version 3 (CCSM3). J. Clim. 19, 2122-2143 (2006).
78. Cohen, K. M., Finney, S. C., Gibbard, P. L. \& Fan, J.-X. The ICS International Chronostratigraphic Chart. Episodes 36, 199-204 (2013).

79. Bowring, $\mathrm{S}$. A. et al. U/Pb zircon geochronology and tempo of the endPermian mass extinction. Science 280, 1039-1045 (1998).

\section{Acknowledgements}

This research was funded by collaborative research grants from the National Science Foundation (EAR-1636625 to C.R.F. and T.D.F. and EAR-1636629 to A.W. and C.W.) Funding was also received from the Swedish Research Council (VR grant 2015-4264 to V.V., and VR grant 2014-5234 to S.M.).

\section{Author contributions}

C.R.F., T.D.F., S.M., V.V., C.M., R.S.N., and M.B. examined and sampled the PHKB-1 core and performed field investigations. C.R.F. contributed to sedimentology; T.D.F. and A.P.T. geochemistry; S.M., V.V., and C.M. palaeobotany and palynology; R.S.N. and J.L. C. were responsible for geochronology, and A.W. and C.W. performed climate model simulations. C.R.F. compiled the paper and all authors contributed to manuscript refinement.

\section{Additional information}

Supplementary Information accompanies this paper at https://doi.org/10.1038/s41467018-07934-z.

Competing interests: The authors declare no competing interests.

Reprints and permission information is available online at http://npg.nature.com/ reprintsandpermissions/

Publisher's note: Springer Nature remains neutral with regard to jurisdictional claims in published maps and institutional affiliations.

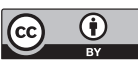

Open Access This article is licensed under a Creative Commons Attribution 4.0 International License, which permits use, sharing, adaptation, distribution and reproduction in any medium or format, as long as you give appropriate credit to the original author(s) and the source, provide a link to the Creative Commons license, and indicate if changes were made. The images or other third party material in this article are included in the article's Creative Commons license, unless indicated otherwise in a credit line to the material. If material is not included in the article's Creative Commons license and your intended use is not permitted by statutory regulation or exceeds the permitted use, you will need to obtain permission directly from the copyright holder. To view a copy of this license, visit http://creativecommons.org/ licenses/by/4.0/.

(C) The Author(s) 2019 